\title{
SPECTACLES OF SEXUALITY: Televisionary Activism in Nicaragua
}

\section{CYMENE HOWE}

American University

T.V.— is it the reflector or the director? Does it imitate us or do we imitate it?

—The Disposable Heroes of Hiphoprisy, "Television: The Drug of the Nation” (1991)

\section{THE REVOLUTION WILL BE TELEVISED}

Sundays in Nicaragua are a day for visiting; ${ }^{1}$ they have also become a good day to watch TV with family and friends. On a rainy Sunday in late March, Elena's father, now in his early nineties, walked the three miles, as he often does, from his house to his daughter's. ${ }^{2}$ Elena and I, along with her daughter and father, gathered around the television to watch an eagerly awaited melodramatic climax: E1 Sexto Sentido (The Sixth Sense) would, at long last, resolve the looming dilemma faced by Sofía, one of the show's protagonists. A few episodes earlier, Sofía decided to end her relationship with her longtime boyfriend, Tomás. Tomás had recently proposed to her with a diamond engagement ring (a rare nuptial token in Nicaragua, although one that would signal one as being economically well endowed), but Sofía declined his offer of marriage. Tomás wanted her to abandon her studies, marry him, and move to the hinterlands. Sofia finally had to tell her mother that she was not going to marry Tomás. She was, however, pregnant. For the past few weeks the TV show had focused on Sof'a's deliberations. Should she have the 


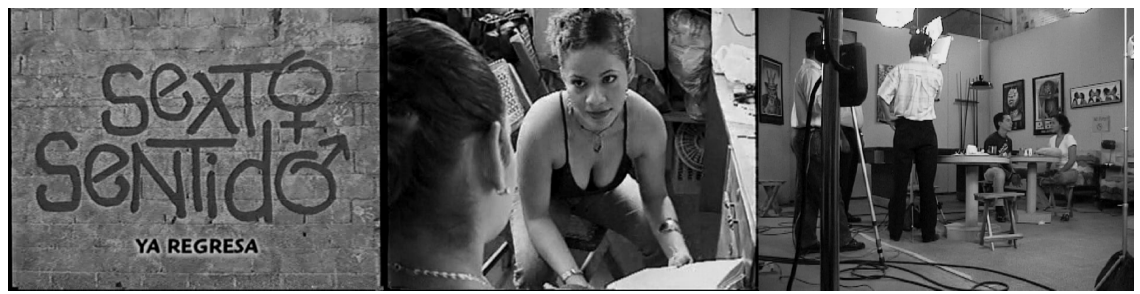

FIGURE 1. In the television show Sexto Sentido, a telenovela (soap opera) format is used to promote social change and mediate dialogues about sexuality and gender roles among viewers, particularly Nicaraguan youth and their families. Backstage, the actress who plays Vicki, the show's lesbian character, explains that she was excited to play the controversial role. On the set, taping an upcoming episode, Vicki converses with Eddy-a character who often serves as the melodramatic foil for the progressive message of the TV show. Photo by Cymene Howe.

baby? Should she reconsider Tomás's marriage proposal? How could she possibly take care of a baby and continue at the university? Sofía had been considering an abortion, an act that would be illegal in Nicaragua. Elena assured me as we sat down to watch the program that if Sofía were to have an abortion, the Church and the Nicaraguan government would, in her words, "censor" the show and remove it from the air. Elena's commentary about potential censorship underscored the political volatility of abortion in Nicaragua in the past and, perhaps more virulently, in the present. Elena's theory about censorship, however, was not to be tested at this juncture. Sofía did not get the abortion. But thousands of Nicaraguan teenagers and their families were poised at the edges of their seats waiting to see what would happen if she did. Beyond the scripted world of Sofía and her moral strategizing, these episodes broached subjects that are central to many Nicaraguans, demonstrating some of the overlap between televised and "real” worlds. (See Figure 1.)

Television, the small screen that has become central to much local knowledge in Nicaragua, is a place where predictable dramatic tropes of betrayal, heartbreak, and forgiveness become part of many Nicaraguans' daily diet of telenovelas (soap operas). Representations of gender and sexuality that appear on Nicaraguan television screens reflect images familiar in the global mediascape of syndicated U.S. TV shows and blockbuster movies. The outrageous queen and effeminate gay men are fairly regular fare on Nicaraguan TV, although lesbian characters, as elsewhere, are nearly nonexistent. ${ }^{3}$ However, Sexto Sentido, a show produced by a Nicaraguan feminist NGO, intends to offer something different, and the show has many people watching. Coupled with polling data that claims that 70 percent of the entire Nicaraguan viewing audience and 80 percent of 13 to 17 year olds watched the show, there were clearly a huge number of Nicaraguans who were faithfully tuned in to Sexto Sentido when it screened between February 2001 and July 2005 . $^{4}$ 
Included in Sexto Sentido's broader audience was the director of USAID's Managua office. He told me one afternoon in 2001 that the agency considered Sexto Sentido "a model" for development in the Third World. Was this successful social engineering on a shoestring budget, or a powerful and popular means of inciting dialogue in the public sphere, or both?

This article analyzes how particular forms of knowledge regarding sexuality and gender are produced and disseminated through Nicaraguan television. I argue that a unique social justice TV show, Sexto Sentido, has aimed to maintain a dialogic relationship with its audience, thus engaging the Nicaraguan state and nation in a mediated conversation that intends to actively transform social values. First, I suggest that the program was both created and viewed interactively, allowing for a more integrative analytic: one that does not starkly distinguish between the frames of "production" and "reception" that have confounded many studies of the media, culture, and social change. Second, I discuss how transnationally familiar gay and lesbian characters and reproductive rights discourses have been utilized in these advocacy campaigns - campaigns that I consider "televisionary" in their approach. These media discourses and representational strategies are aimed at normalizing queer subjects. However, this is done with an eye toward producing a sense of locality, one that is intimately familiar and suited to the Nicaraguan context; these moves, therefore, problematize rigid distinctions between the pan-national and the situated-local. Local sexual subjectivities are elided, but they are also made more "palatable" for Nicaragua and (remarkably, given the limited resources available to produce the show) distributed internationally as part of a larger "erotiscape" of images and messages in a global media market.

The universal applicability of identities, and sexual and gender subjectivities, has been a critical question for scholars, particularly as discourses and praxis move more easily and rapidly in the digital and globalized age. Here, I demonstrate that there are feedback loops between the First and Third World, in both the construction of the subject and its mediated representation. I suggest that the dialogic, televisionary approach used by advocates attempts to reframe meaning surrounding reproductive choice and sexual identity, not simply policy; advocates producing these images are intent on reconfiguring what they see as Nicaragua's dominant, socially conservative political culture. Sexto Sentido's producers eschew the term alternative media to describe their program. Instead, they see the show as propagating alternative values and quotidian dialogues in the waters of Nicaragua's mainstream. ${ }^{5}$ 


\section{The Politics of Gender and Sexuality}

In the final chilly years of the Cold War, Nicaragua, a small "Third World" country in Central America, became well known globally for the Sandinista revolution (1979-90). Through the Sandinista era Nicaraguan women became more overtly politicized (González and Kampwirth 2001); North American and European allies traveled to the country in solidarity with the revolution; and contentious politics ensued, from land redistribution to gay and lesbian rights (Field 1999; Randall 1993). With the demise of the revolutionary era in 1990 and the advent of global capitalism, Nicaragua has taken on a new "identity" as the second-poorest country in the Western Hemisphere. Beginning with the reign of Violeta Chamorro in 1990, the first elected female president in Latin America, several socially conservative and neoliberal regimes have governed Nicaragua; and it is against increased conservatism, in the legal and "cultural" realms, that gender and sexuality advocates find their struggle.

In the wake of the revolutionary state the country also experienced profound political changes, including what Nicaraguans call el boom of NGOs, the growth of an autonomous women's movement, and a series of luchas (struggles) for sexual rights. Nicaraguans have overthrown a dynastic dictatorship that ruled for nearly 50 years, but social transformation is now largely tied to the good graces of foreign allies, governments, and NGOs. Contemporary sexuality and gender activism, at the grassroots and NGO levels, often focuses on preventing intrafamilial violence, providing reproductive health care, ensuring lesbian and gay rights, and educating young people. Abortion continues to be, as it was during the Sandinista era, a hotly contested issue. The procedure has been illegal in Nicaragua, with the exception of the 100-year-old law allowing "therapeutic abortion" when a woman's life is in danger. Homosexuality is also the subject of pathologizing discourses and moral invocations by the Catholic and Protestant churches.

In 1992 the Nicaraguan National Assembly increased the criminal sentence for sodomy. Article 204, which several human rights organizations have dubbed "the most repressive" antisodomy legislation in the Americas, states that "anyone who induces, promotes, propagandizes or practices in scandalous form sexual intercourse between persons of the same sex commits the crime of sodomy and shall incur 1 to 3 years' imprisonment." The growth of gender and sexuality NGOs and advocacy groups has been motivated by legislative restrictions such as the antisodomy law and deterioration in public health provision. ${ }^{1}$ But their work is also grounded in opposition to a broader phenomenon that activists call "fundamentalism." This includes antiabortion campaigns by religious institutions, primarily the enormously influential Catholic Church; controversies regarding sexuality curricula in schools; and "fiscal terrorism" against women's organizations and personal attacks on their leadership. Advocacy affiliations such as the Women's Network against Violence and sexual health and rights NGOs that sponsor the weeklong "Sexuality Free from Prejudice" events in late June every year (films, research presentations, discussions at universities, distribution of information, and celebrations) sometimes work in tandem, and sometimes apart, on issues critical to gender and sexual justice. The women's and feminist movement in Nicaragua is 
quite well recognized (both nationally and internationally) for successfully initiating cultural and legislative changes, particularly in the arenas of sexual abuse and domestic violence prevention. Gender advocates are also recognized for their theoretical sophistication, innovative political practices, and international influence (Kampwirth 2004). The centrality of gender and sexuality in popular venues such as television and print media, as well as in public discourse, suggests the significance and historical tenacity of these issues. However, gender and sexuality politics are for many (including, at times, avid advocates themselves) sometimes secondary to the pressing economic issues that continue to hobble the hopes of many Nicaraguans.

The 2006 elections saw the return of Daniel Ortega to the presidency leading a (much changed) Sandinista Party. Ortega's newfound Christian rhetoric, neoliberal economic plans, and alliance with Venezuela's Hugo Chavez all facilitated his reelection by a very slim margin. Ortega was also able to overcome earlier accusations of rape and incest leveled by his adopted daughter, Zoilamerica Narvaez. This widely publicized scandal, in addition to Ortega's perceived failures as president during the 1980s, foiled his political aspirations for several years (Kipnis 1999). During the heated election campaign, with mounting pressure from the Catholic Church and both of the leading political parties, abortion, including therapeutic abortion, was entirely criminalized. This places Nicaragua among a small minority of nationstates that prohibit all access to abortion. Several international organizations have lobbied the Nicaraguan government to rescind this move (Sirias and Barbarena 2006; Vigíl 2006), and numerous maternal deaths have resulted as of this writing.

\section{NOTE}

1. For useful overviews of lesbian and gay political movements in Nicaragua, see Babb 2003; Howe 2002; Randall 1993; Thayer 1997.

\section{CHANNELING TRANSNATIONAL IDENTITIES AND POLITICS}

Anthropology and the study of public culture have sought to understand the complex exchange between various forms of media and social life (Appadurai and Breckenridge 1988). Although transnational exchanges are not entirely novel (Harvey 1990), "mediascapes" or "flows" (Appadurai 1996) of information, technology, and content have accelerated and intensified, creating what many observers believe to be "qualitatively new cultural phenomena" (Donham 1998:6). Corporate, Western, and northern media sources — such as Hollywood, CNN, and MTVhave appeared to be hegemonic arbiters of media over much of the world (Askew 2002:1). But, the more recent appearance of media outlets such as YouTube has created a more nuanced dynamic. It has led to an increased "democratization" of new media in tandem with expanded corporate media consolidation. The shifting ground of global media underscores that counterhegemonic media forms have 
existed before the widespread use of video uploads online. These include video productions by indigenous peoples (Ginsburg 1993; Turner 1992, 2002), Third World soap operas (Abu-Lughod 2002, 2004; Mankekar 1999), innovative applications of digital technologies (Berry et al. 2003; Smith and Mantz 2006), and the use of film and television as social activist genres in the developing world (Downing 1987, 2001; Rodríguez 2001). Ethnographic attempts to understand the particularities of media production as well as relations of consumption have attempted to comprehend "media" and "culture" not as distinct entities, one operating on the other in an instrumental way, but, rather, as ongoing reciprocal processes of mediation (Boyer 2007, 2005; Dávila 2001; Friedman 2006; Ganti 2002; Mazzarella 2003, 2004; Pedelty 1995; Schein 2002).

The interrelationship between technology and content is important, but of equal significance are the ways in which media consumers and media producers are mutually constituted through historically specific discursive practices and politics. The Nicaraguan case is but one example. As feminist and sexuality rights in Nicaragua are framed through television as medium and message, activist-producers seek to avoid a hierarchical dissemination of media messages handed down from creators to viewers. Instead, they search for answers from their target audience, hoping to make this a reciprocal process and one of communicative salience- a utopian engagement with Habermas's (1992) “public sphere.” These productions are meant, I argue, to be a televisionary feedback loop on both local and global levels. With their messages of homosexual identity and reproductive choice, these media strategies are intended as an implicit challenge to state law, which mandates stiff penalties for the "promotion" or practice of homosexuality, and an abortion ban. These media interventions also seek to provoke social dialogue around the contentious topics of abortion, domestic violence, sexual abuse, homosexuality, and lesbianism in Nicaragua's communicative landscape. However, as I will suggest, they also do something more. These productions simultaneously seek to normalize relatively novel characters in Nicaragua's erotiscape: the "gay" and "lesbian"internationally circulated identity categories that stand in some distinction from Nicaragua's more autochthonous (and derogatory) categories: the cochón (fag) and cochona (dyke [Babb 2003; Howe 2002; Lancaster 1992]). ${ }^{6}$ Although distinctions between the "local" and the "global" have become slippery stuff for social science in the era of globalization, it is through carefully crafted productions of a very specific Nicaraguan "locality" that advocates aim to present their political agendas and televisionary messages. ${ }^{7}$ Through appeals to the familiar and the local, transnational ideological materials concerning sexual and gender rights are brought "home." 
However, these advocacy frames do have their epistemological limits; only certain sexual subjects or feminist concerns make their way to Nicaragua's small screen.

As the preferred entertainment medium in Nicaragua — one that is ubiquitous, inexpensive, and seemingly always "on”- television as a political messaging device is seen by many advocates as a uniquely effective advocacy tool. Here I consider what I call "televisionary" activism — a mediated form of social justice messaging that utilizes the pervasive, popular platform of television to create new "visions" of social transformation to shape and change, in the words of advocates, "culture." These practices, linked to larger social movements for sexuality and gender rights, tactically maneuver transnationally available content - including global iterations of identity politics - to challenge the marginalization of youth, women, and sexual minorities in contemporary Nicaragua. ${ }^{9}$ I consider several levels of these media interventions, including the dialogic desires embedded in these televisionary advocacy practices. I work through several ethnographic dimensions, including the scripting, filming, set production, focus groups, and popular reception of the show. Rather than focusing solely on audience reception, I look to how media messages are crafted and how knowledge becomes produced. Televisionary strategies, as I will show, are ideologically dedicated to a more "organic" and dialogic process where audiences are engaged with the show's creation and shape, not simply receptive. ${ }^{10}$ I first set the stage by briefly considering a transnationally syndicated television show, Betty La Fea (now Ugly Betty in the United States), which aired in Nicaragua to much popular acclaim. The show's gay male character roused much debate during a "Sexuality Free from Prejudice" event in Managua. I evoke this debate here to highlight the contentious construction of homosexuality in contemporary Nicaragua. I then turn more detailed attention to a "local" media production, El Sexto Sentido, to consider how characters are scripted, produced, and viewed with political ends in mind: that is, how characters have been crafted to have a social justice effect through their particular affect.

\section{BROKEN-HANDED HOMOS AND UGLY BETTY}

In 1992, following the end of the Sandinista revolutionary era and coinciding with a more generalized conservative turn in state politics, the Nicaraguan National Assembly increased the penalties of the country's antisodomy law, making it, according to Amnesty International, the "most repressive" antisodomy legislation in Latin America. Being a cochón (an "effeminate" or "passive" man who has affective and sexual relationships with other, often more masculine, men) 


\section{Media and Representational Politics}

Popular media in Nicaragua, as in many places, has a powerful influence on political dialogues. As in much of Latin America, the history of media - in the form of print, radio, television, and film - is uneven and variegated. Brazilian television, for instance, was instrumental in upholding dictatorship (Skidmore 1999:171). In Cuba a flourishing film industry has marked the revolutionary period with its socialist aesthetic (Chanan 2004). In Mexico various forms of media, from films to comic books, both reflect and inspire various forms of national identity (Lomnitz 2001; Rubenstein 1998). The ways in which Nicaraguan activists are now implementing media in their work must be set in context with the broader regional ways that media has uneasily moved in national discourses and politics (Anderson 1983; Lomnitz 2001).

During Nicaragua's dictatorial period, tacit support from the U.S. government paved the way for U.S. media interests - from individual corporations like Disney to a more generalized fecundity for Hollywood productions and U.S. television (Whisnant 1995). Nicaragua had little cinematic culture per se; there were very few theaters and virtually no native filmmakers. During the revolutionary era the Sandinista state launched an innovative cinematic tradition of its own with the development of the government-sponsored Nicaraguan Institute of Cinema (INCINE). The work of INCINE was inspired by Cuba's revolutionary filmmaking and technical support; it was also motivated by the ever-brewing excitement about a "new" Latin American cinema with an anti-imperialist ethos. Creating nearly 70 (mostly short) films, INCINE was meant as "a project of constructing or recovering national identity" (Buchsbaum 2003:xvi). Notably, the films and newsreels it produced did not simply mirror the Sandinista Party line but reflected the aesthetic and political interpretations of filmmakers themselves.

Although Nicaragua has not had a well-developed autochthonous television and film production infrastructure, the country has long made use of other forms of "new media." Print journalism was a staple of the revolutionary era and continues to shape quotidian discourses. The widely circulated national newspaper, El Nuevo Diario, for instance, features a weekly supplemental section entitled "Health and Sexuality," which features news items on homosexuality, sexually transmitted diseases, sexual fantasies, and adolescent sexuality, among others. Radio, a medium that is both expensively produced and received, has also been a key tool for political advocacy in Nicaragua as in much of Latin America. NGOs and individual grassroots activists currently air radio programs discussing adolescent sexuality, homosexuality, pregnancy, gender dynamics, domestic violence, and machismo. These shows are often dialogic, inviting calls from listeners and on-air conversations on the touchy topics of sex and gender. The use of popular education materials, again instrumental for popular insurrection and pedagogy, is also at work in contemporary gender and sexuality advocacy practices. La Boletina, a free, feminist magazine published by the NGO that produces El Sexto Sentido, has the largest circulation of any magazine in Nicaragua. Other magazines such as Fuera del Closet (Out of the Closet [published by a Nicaraguan NGO]) and Humanas (a lesbian visibility magazine) are less widely distributed, although they are available to interested seekers. 
The Internet continues to gain importance among advocates, particularly as organizations develop informational websites, some of which encourage visitor feedback and postings. However, these websites may speak more to an international audience than a national one, as the great majority of Nicaraguans continue to have only intermittent or no access to the Internet. Nicaraguan urban youth are online seemingly whenever they are able, at Internet cafés or at home among upper- and middle-class Nicaraguans. This generation and their digital age will almost certainly transform the next iterations of media and advocacy in the country and beyond its borders.

or a cochona (a "masculine" woman who has affective and sexual relationships with other, often more feminine, women) has never been an honorable designation in Nicaragua. But neither have these subject positions been wholly vilified or the object of the sort of homophobia found in some other settings. Like other contexts in Latin America, Nicaragua has held "fags" and "dykes," especially those who transgress gender norms, in disregard and often ill repute while still recognizing them as part of a larger gender and sexual system along a continuum of masculinity and femininity (Kulick 1998; Lancaster 1992), rather than simply sexually transgressive (Carrier 1995; Parker 1998; Priuer 1998).

Since the new stringencies of the antisodomy law, sexual and gender rights advocates have developed a number of responses, including hosting annual "Sexuality Free from Prejudice" events in late June. At the "Sexuality Free from Prejudice" events in 2001, sponsored by a number of Nicaraguan NGOs and activist groups, a panel of experts and commentators gathered to discuss issues facing gays and lesbians in Nicaragua. An audience member stood to ask the panel members their opinion about something he thought had critical bearing on the situation for Nicaraguan lesbian, gay, or homosexual people. He drew everyone's attention to the hugely popular show Betty La Fea (Ugly Betty). ${ }^{11}$ Everyone knew Betty. Produced in Colombia, Betty La Fea is a telenovela with comedic trappings that was broadcast in the evening in Nicaragua. The show follows the travails of an outrageously nerdy, braces-and-glasses-wearing protagonist, who in the end manages to land her man through ingenuity and a sweet temperament. Betty La Fea does have a "gay" character, Betty's coworker Hugo Lombardi, and it was to him that the commentator pointed. "Now that gays and lesbians are on TV," he suggested, "there is no longer any reason to worry about the acceptance of los homosexuales." One of the panelists, a man long involved in Nicaraguan sexual rights activism, responded to the comment about "acceptance" very emphatically: "This [Hugo] is 
not the kind of homosexual I want to be . . . and I don't think that he [Hugo] represents anything good for gay people." The TV character, Hugo, is very effeminate by North American standards and "broken wristed" by Nicaraguan standards. ${ }^{13}$ Good looking and well heeled, Hugo is one of the show's villains, and he is often cruel to Betty. Hugo does not have a lasting love of his own, unlike the heterosexual characters in the show.

Questions of representation simmered close to the surface in the debate surrounding Betty La Fea's gay character: How "queer" or how "normal" should homosexual or lesbian TV characters be, in Nicaragua or elsewhere? How to best generate respect in a place where historically homosexually marked men and women have faced mockery (burla) or invisibility? For sexuality and gender advocates, Betty La Fea's "Hugo the Gay" reflects the flamboyant end of the spectrum, and whether he could plausibly serve as a representative for all gay people remained contested territory. Hugo's lack of monogamous coupling, his putatively far-tooqueer persona, and his upper-class trappings do result in his eventual loneliness. Perhaps this is the price to be paid for villainy, or perhaps Hugo's sexual "pathos" is at the center of his unenviable fate. As Nicaraguan gender and sexuality advocates point out, visibility is fundamental to the struggle for sexual rights, but exactly how this visibility appears is of equal importance. Partly in response to the antisodomy law and partly linked to their desires to create a more tolerant climate for sexual diversity, advocates in Nicaragua have often opted for a qualitatively different kind of homosexual subject: one who is exceptionally "normal" and one who is, not incidentally, internationally recognizable.

\section{SCREENING SOCIAL JUSTICE}

In January 2001, Sexto Sentido, a unique social justice soap opera, began its soon-to-be-acclaimed appearances on Nicaraguan televisions. The program - a total of 80 weekly episodes - was part of a larger campaign supported by the host organization, the Nicaraguan feminist NGO Puntos de Encuentro (Common Ground), which was born during the early 1990s "boom" in Nicaraguan civil society organizing. The multiyear campaign, "We Are Different, We Are Equal," as with the TV show, reflects the egalitarian and multicultural values of Puntos. After six months of prime-time Sunday afternoon screenings, the TV program was rated the most popular among Nicaraguan youth, its target audience; it also had some of the highest television ratings in the national market. Supported by funds from USAID and other international development programs, Sexto is a telenovela (soap opera) focused on the lives of three young women and three young men. ${ }^{14}$ 
Funding proposals to USAID hailed the show as a Nicaraguan version of the U.S.produced and globally syndicated comedy Friends. However, the show is different from the usual TV programming from the United States, Mexico, Colombia, or Brazil (La Pastina 2004; López 1995; Martín-Barbero 1995; Sinclair 1999). Sexto Sentido is the only dramatic series produced in Nicaragua, and it is shot entirely on location in familiar locales around Managua, with local actors using dichos (colloquial expressions) unique to Nicaragua. As many people told me, they love the show because it is pura Nicaragüense, that is, "really and truly" Nicaraguan. ${ }^{15}$

The production studio of Sexto Sentido lies across from one of Managua's most famous cemeteries, a strange place for a television studio. But this studio is different from those one might find in the United States in its bare-bones simplicity. At the same time, it is similar to any location where movie or television stars spend their time - necessarily a little clandestine. ${ }^{16}$ The studio itself hides behind a 15 -foothigh corrugated metal gate, the sort that is unscalable; it is a typical, inexpensive form of security in Managua. The show's sets, props, and equipment are housed in a large sound- and lightproofed building intended to block ambient street sounds. Nonetheless, during the time I spent watching the taping of Sexto Sentido, the cameras needed to be paused when a dog on the street began barking. The program was filmed using two cameramen armed with Mini Digital Video and Betacam cameras. Before the cameras rolled, all of the big silver fans that squatted around the studio making the temperature almost bearable had to be switched off because they were deemed too noisy. Iliana, the director, would sit at a long table watching two monitors and carefully scrutinize the action as it unfolded on the screens. At times she would halt the dialogue and consult with the actors about how to make it "more real." Once a scene was complete, the metal fans were flipped back on, and brows were swabbed with the little washcloths nearly every Managuan carries to contend with the below-sea-level tropical swelter.

The NGO that produces Sexto Sentido has placed at the center of its mandate "to change culture, not just behavior." The overall objective is to foster notions of diversity and social acceptance, creating a multicultural umbrella of "difference" under which to shelter those who do not benefit from the status quo. Sexto Sentido's director described to me one afternoon that the TV show aims "to affect public opinion and promote values and relations of justice and equality." To transform social values, she went on, the TV characters themselves must undergo "a process of self-discovery," which will then, presumably, be mirrored by the viewing audience. The self-discoveries she noted were those of "identities, the changing roles of men and women, romantic and sexual relationships, and self-esteem.” These processes 
of self-discovery and social transformation could be said to share a kinship with concientización practices associated with Paulo Freire (1973) that were a part of Nicaragua's revolutionary period, but here they are married to a multiculturalist discourse of identity, self-fulfillment, and subjectivity. The pedagogical focus on "identity" is critical to the show's social marketing, and both gender and sexuality are central to these identity formations.

In addition to pedagogies of identity, the creators of Sexto Sentido hope to create a dialogic process between themselves and their audience. The credits that roll at the end of each episode invite viewers to e-mail or write with their suggestions for the program. Since the beginning of the show, the producers have incorporated suggestions they have received from viewers, particularly Nicaraguan youth. The NGO also held a contest where teenagers were asked to write letters about how gay characters on the show had affected their lives. They received hundreds of responses indicating how much viewers appreciated the gay characters and their unfolding identities. The winners of the contest were invited to a party where they were able to mingle with the stars of this social justice soap opera. The philosophy that the producers believe guided the show, egalitarian principles and a democratic approach to social justice, makes use of what Gramsci understood as "organic intellectuals." The ideal of dialogic communication with audiences nurtures a televisionary circuit that is a central ideological apparatus for these performances of mediated social activism.

Well-funded Nicaraguan NGOs such as Puntos have found the means by which to frame social change in simultaneously subtle and yet spectacular (Debord 1995) visible forms. Through television shows that are educationally driven and founded in progressive politics, advocates attempt to channel their messages of social change. By producing performances of gender and sexuality that provide an alternative to hegemonic forms the show makes political use of the quotidian ritual of telenovela watching. These media interventions are meant as a pedagogical antidote to perceived injustices. As such, they follow a similar logic to other instances of socalled edutainment — where instruction is explicitly woven into an "entertainment" forum (Barnett 1999; Buckingham and Scanlon 2005; Rodríguez 2001). ${ }^{17}$ They are didactic in nature, although not at the expense of entertainment value. And despite the antisodomy and antiabortion laws, these media representations seem to have thrived. 


\section{FRIENDS, “ISMS,” AND DARK ALLEYS}

As “a pro-social entertainment television series," Sexto Sentido was intended to provoke dialogue among Nicaraguan youth and their families. As one of the show's producers put it, "By entertaining we are best able to get our message across." The show addressed issues of sexuality, reproductive health, intrafamilial violence, sexism, racism, classism, homophobia, discrimination against disabled people, prejudices against costeños (Nicaragua's Atlantic coast population, who are largely of African descent and Creole speaking), and biases against campesinos (farmers, country folk), among other things. It treated nearly every "ism" imaginable in Nicaragua; but it was also entertaining and often funny. The proposal written to develop the TV show explained that "we consider this project to be particularly urgent now, when a positive vision and self-image is crucial to getting people and the country back on their feet ... [and] we hope the series will be aired in neighboring countries." The television show covered many issues that are sensitive not only in Nicaragua but also in other parts of Latin America and around the world. One of the more volatile and controversial issues, as Sofía's choice at the beginning of this article showed, is abortion — a tema tabu (taboo topic [Vigíl 2006]) that the show carefully and bravely addressed.

Although Sofia kept her baby and managed with the help of her friends, it was not long before the issue of abortion was reintroduced, this time through the character Franky. On her way to a party Franky is raped by a stranger in an alley in Managua. The rape scene is dark and troubling, especially because it cuts back and forth between Franky's rape and struggle and her friends enjoying the party, laughing and dancing. Whereas Franky is attacked in shadowy terrain and unsuccessfully tries to fight off her attacker, the majority of rapes in Nicaragua do not take place in dark alleys but, rather, in familiar settings, often by men known to them. Attempting to disabuse the viewers of the common misconception that rapes happen in dark alleys, the show features an epilogue at the end of the episode that notes crime statistics on rape in Nicaragua, emphasizing that most rapes happen in homes and are perpetrated by men known to them. (See Figure 2.)

Several weeks later in TV time, Franky realizes she has become pregnant because of the rape. She now faces the abortion dilemma. Worrying that "people will point their fingers at me and damn me to hell," Franky struggles with the decision, argues with her boyfriend who advises against it, and talks with friends (and Sofía in particular). After many, many tears, Franky decides to have the abortion. She asks Sofía for help and support, and the two young women discuss how many women die through botched illegal abortions; Franky also fears potential 


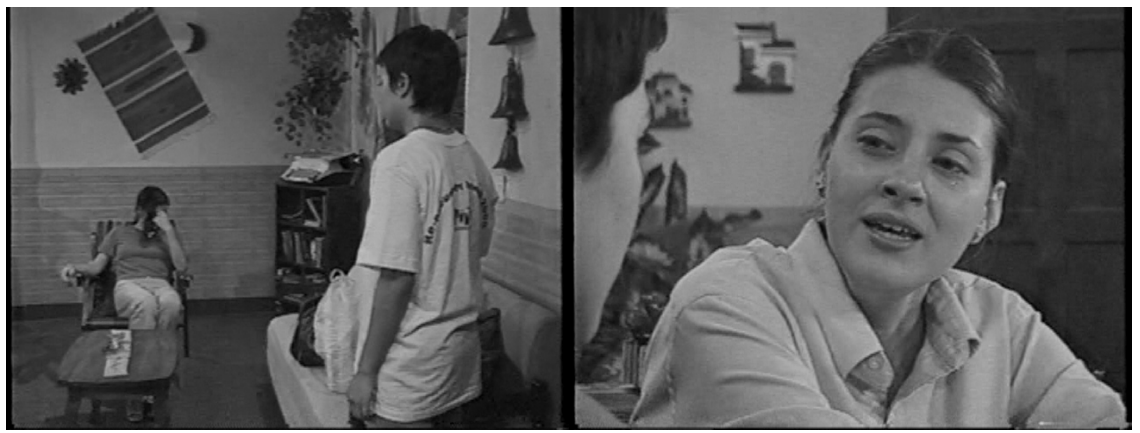

FIGURE 2. In the first frame, the TV character Sofía confesses to her mother that she is pregnant. Her mother is upset and worried about her daughter's future. Sofía wears a T-shirt promoting the NGO project that produces the television show, "Somos Diferentes/Somos Iguales" [We Are Different/We Are Equal]. The character Franky, her face wet with tears, later confides in Sofía her fears about her own pregnancy_caused by being raped—and pending decision to have an abortion. Photo by Cymene Howe.

arrest. Ultimately she finds a medical office armed with money she has borrowed from her parents. Notably, Franky is by far the wealthiest character on the program, and viewers are privy to her family's upper-middle-class status - they have a maid, luxurious furnishings, and a taste for fine wine. Franky's ability to go to a private clinic and undergo a relatively sanitary and safe procedure is possible only for those women with adequate funds. It is a middle- and upper-class remedy in a place where - as the second-poorest country in the Western Hemisphere - the middle class is relatively elite. The TV show elides some of the socioeconomics of abortion and represents the realities of rape in Nicaragua as an afterthought, rather than developing a more realistic portrayal of rape in the plotline. ${ }^{18}$ This narrative move risks abstracting rape and abortion from their real-life tethers, but Sexto Sentido's portrayal of Franky's decision, nonetheless, was bold: confronting both the Nicaraguan state and powerful Church positions on abortion. At the same time, these narratives "air" controversial subjects for the consumption of Nicaraguan viewers. Compared with the case in the United States, where audiences have not been exposed to a network TV character who has successfully undergone an abortion since the television show Maude in the 1970s, Franky's decision is a challenge to the status quo. ${ }^{19}$ Despite Elena's earlier predictions about Sofía, the TV station was not closed down or censored. In fact, Cardinal Miguel Obando y Bravo, the official voice of the Catholic Church in Nicaragua at the time, was uncharacteristically quiet.

Within the next few years, however, Nicaraguans would be challenged by another unintended pregnancy. This one was the result of a real rape of a 
nine-year-old Nicaraguan girl, known as "Rosa," while her family was temporarily working in Costa Rica. When the family returned to Nicaragua the girl's case generated virulent debate about abortion, raising questions such as "Can a nineyear-old girl be a mother?" and "Shouldn't she be allowed to have an abortion?" (Galeano 2003; Juarez Ordoñez 2003). Women's rights activists were also moved to march in the streets, proclaiming that "all little girls that become pregnant have been raped - she has a right to a therapeutic abortion" (Vigíl 2006). Despite her age and the danger to her physical and psychological well-being, the Catholic Church hierarchy in Nicaragua insisted she carry the pregnancy to term; other conservative forces in Nicaragua also weighed in, and some were accused of "kidnapping" the girl to prevent her from undergoing the abortion (Kampwirth 2006:74). The case became an international controversy, taken up by pro-choice advocates, including the (Nicaraguan) Network of Women against Violence, and antiabortion proponents, including the president of the republic and the Catholic Church hierarchy. Ultimately, this transnationally observed tragedy ended in the girl having the abortion at an undisclosed clinic in the middle of the night (Amnesty International 2004). Cardinal Miguel Obando y Bravo made clear in the Sunday Mass following Rosa's abortion that all those responsible for the procedure would be automatically excommunicated (Velásquez Sevilla and Pantoja 2003). The truth is more disturbing than fiction in this case and others — now that Nicaragua's long-standing “therapeutic abortion” law has been overturned (in October 2006). An abortion can no longer legally be performed to save a woman's life, and maternal deaths are on the rise (Franco et al. 2006; Sirias and Barbarena 2006; Sirias and Dávila 2006).

\section{NORMALIDAD AND ANGELIC GAY MEN}

Angel has been Sexto Sentido's gay protagonist since the show's inception. As the show's director explained, "The issue of homosexuality has always been discussed openly because one of our principle characters is gay." The show's producers assured me that Angel's name was purely coincidental; nonetheless, Angel is fairly angelic. Angel is, a screenwriter explained, “so damn likable, it's impossible to hate him for anything. That's the kind of gay character we have to create: one that is beyond reproach." Angel often serves as a foil to Eddy, the show's bad boy of sorts. In early episodes Eddy chides Angel, “Aren't you into Sofía?” Angel answers, "Nah. ... She's not my type." And Eddy teases him, in his off-color way, "Vos sos un cochóncito" or "You're a little fag." Washing clothes, almost always done by hand in Nicaragua, is considered women's work, and laundering clothes, in 
particular, is often considered one of the "marks" of homosexuality in men. ${ }^{20}$ Thus, when Angel is caught at the backyard pila (a cement sink used to wash clothes by hand), Gabriel, another key male protagonist, charges, "If you wash your [own] clothes, you are cochóncito ... a cochón isn't a real man.” Gabriel's comment, in the pithiest of ways, demonstrates how male homosexuality becomes detached from "true" masculinity. Angel makes a plea on behalf of his own masculinity when he responds to Gabriel, “I am a man. . . . Just because I like men doesn't make me any less of a man.”

Angel is declarado to most of his friends on the show as being attracted to men, and he has a boyfriend, Christian. ${ }^{21} \mathrm{He}$ and his boyfriend have an apparently "egalitarian" relationship as opposed to a "gender role-based," homosexual coupling. Evoking globally circulated notions of egalitarian and gender-neutral homosexuality neither Angel nor his boyfriend is more "macho" than the other, and neither of them ever behaves like a loca (queer or queen). ${ }^{22}$ Angel is also very successful and has accomplished goals that many Nicaraguans would admire, including earning a scholarship to study in Mexico. Before leaving for his studies farther north, Angel wants to come out to his parents, who are campesinos. He explains to them, "I want you to know so that you understand me ... I like men. I am a homosexual." Angel's parents react negatively at first. His father glares at him and walks away, and his mother breaks down in tears, asking what they had done wrong. Ultimately, they accept their son's identity, most pointedly through his father's comments, "Sos mi hijo" [You are my son] and "May God bless you." Angel has indeed been exceptionally "good," even if his parents are concerned about their son's newly explicit sexual reality.

Given that Sexto Sentido's producers did not know whether the show would be funded for a second season, Angel's character as a declared homosexual was clearly a high-priority performance. Homosexual subjects such as Angel do exist in Nicaragua, but his experience, although fictional, does not match the character (or caricature) of the local, cochón, maricon, or loca. Angel's coming out to his parents suggests several dynamics at work. Angel's parents were not apparently aware, or did not publicly acknowledge, Angel's being “gay,” making disclosure necessary. In other words, he had performed a presumed heterosexuality - and a form of masculinity - so well that his parents were unaware, or perhaps in willed denial, of his homosexuality. Angel's success, his receipt of a scholarship, and his coming out directly to his parents are unfamiliar occurrences for many sexual minorities in Nicaragua who regularly face discrimination at school and 
at work and who might not be inclined to attempt such direct declarations of sexuality to their parents. In Nicaragua, as in other Latin American contexts, many lesbians and gay men do not come out but are instead covertly recognized by their families. Angel's pronouncement thus has much more in common with an “epistemology of the closet" (Sedgwick 1990), that has permeated Western mores surrounding homosexuality. Angel's character performs a special kind of queer being: the "homosexual" rather than the cochón. Angel, his boyfriend, and his revelatory process represent a particular configuration of a homosexual subject, one that may be more familiar to those making funding decisions at USAID than to average Nicaraguans. Internationally circulated images of gay men are adopted here, but these images are also adapted within a localized context in Nicaragua, in the heartland of the campo, and in a TV serial that consistently evokes familiar Nicaraguan scenes, expressions, and sensibilities. The show's erasure of subjects such as the cochón forecloses visibility for some sexual subjects while highlighting the would-be libratory potential of others.

\section{FEMININE FEEDBACK: FOCUS GROUPS AND GIRLS NEXT DOOR}

The character Vicki made her first appearance on Sexto Sentido in the first season, wearing all the regalia of well-groomed girlhood in Nicaragua: lipstick, hair clips, strappy tank tops, and tight, hipster jeans. Vicki is suited to many young Nicaraguans' ideals of femininity; and Vicki was soon to become Sexto Sentido's lesbian protagonist. The episode where Vicki "declares" herself as a lesbian had not yet been publicly screened when I attended a focus group the show's producers had convened with female viewers between 15 and 24 years old. The focus group was meant to gauge potential reactions to Vicki's disclosure so that interventions might be made, perhaps an epilogue at the close of the show. Bringing together a focus group, although it mirrors some of the most notoriously effective marketing strategies of the corporate world, also suits some of the ideological underpinnings of the show. It was another installment in the producers' ongoing engagement with the show's audience - seeking reciprocity between creators and consumers.

The plot tension between Vicki and her best friend, Alejandra, has focused on a particular subtext - namely, that Alejandra suspects that Vicki might have some designs on her. From Alejandra's point of view Vicki would do things like shower Alejandra with a little too much attention. Alejandra confronts Vicki and tells her, "Look, I don't like women. I want a boyfriend, not a girlfriend," to which Vicki replies, "Who says I'm looking for a girlfriend?" There has been much talk around Vicki's potential lesbian desires_- between Alejandra and Angel and in 
more obtuse terms between Alejandra and Vicki — but until the episode that was screened for the focus group, Vicki's lesbianism existed only in innuendos, hints, and glances. After Vicki's scene of declaración, Alejandra and the viewing audience will be left without a doubt. Vicki states simply, “Ale, you know that I'm a lesbian, right? I mean, all the times we talked about the topic. ... I thought you knew." Alejandra, despite the simmering narrative buildup, is surprised by this very plain and clear divulgence. However, before Vicki's sexuality became the stuff of social transformation in the world of the telenovela and before any declaraciones were made to the viewing audience, Vicki's imminent disclosure was first subjected to a trial run.

After viewing scenes of Vicki's declaration and Alejandra's ensuing rejection, the seven focus group participants were asked to comment on each of the characters and their behavior. One young woman said, "Well, I see Vicki as normal and that she should be treated like a normal person, like one of us." Another added, "We should accept her like a normal person." The facilitator questioned further: "So, Vicki is not normal because she is a lesbian?" to which a girl answered, "Yes, she's a normal person, the only thing is that she likes women.” But another disagreed, "In this sense, because she likes women, she's not normal, but the rest of her, yes, is normal." Clearly, the young women were still processing the idea of Vicki's normalcy; they were, as a group, undecided as to whether she was really, or only partially, "normal" in terms of her sexuality. Vicki did undoubtedly appear normal to the focus group because of her feminine mannerisms and appearance, essentially on every count except for her sexuality. Her gender conformity and embodied femininity were performed in such a way so as to subvert Vicki's homosexual "difference." This move also indexes the salience of gender within the cultural configurations of sexuality.

The next set of questions for the focus group probed deeper and encouraged participants to apply the TV lesson to their own lives. After reviewing the scene where Alejandra is disturbed by Vicki's confession, the facilitator asked, "What do you think about the way Alejandra acted toward Vicki? What would you have done?" The question caused pause. After some thinking, one young woman responded, "Ale should help Vicki to not be a lesbian anymore.” Another participant countered, "Ale should accept her [Vicki]." It was also suggested that "Ale should tell her to go out with guys so that she can get rid of this lesbian thing."

When the participants were asked whether anything similar had happened to them or anyone they knew, much silence followed. Finally, one young woman responded, 
Last year at school, there was this girl, Corelia. She always dressed like a guy, and I think she was a lesbian. And they said that she was with this other girl, Luisa, and one time Corelia, la cochona, invited the other one over to her house, and she invited her in her room .... and [Corelia] told [Luisa] that she was in love with her. Then Luisa took off and told Corelia she never wanted to see her again. So Corelia left school right after that and disappeared, and no one ever saw her again.

The girls in the focus group did translate the events of the small screen into their real-world encounters. However, there is a substantive difference between the real-life gay girl, Corelia, and Vicki, the televised lesbian. The slippage between the terms cochona and lesbian is one indicator of the tensions between the concepts and the characters. Corelia "dresses like a guy," whereas Vicki is always clad in trendy gear and lipstick.

Vicki's superficial markers, her middle-class style and "feminine" appearance, effectively create a dyke who looks a lot more like the girl next door. Vicki, like Angel, embodies a homosexual character that is unlike the neighborhood cochona so familiar to the Nicaraguan audience. Instead, and not unlike Angel, Vicki represents a novel form of being: a "lesbian" rather than the more familiar "cochona." Indeed, more than a few times during the focus group discussion the participants began to refer to Vicki as "la coch-" only to correct themselves, "I mean, la lesbiana." The corrective here is important, suggesting shifts in discourse and possibly meaning. Maybe the girls were performing for the facilitator and the gringa anthropologist. In any case, their words suggest that they were learning that "lesbians" represent a different, didactically privileged, and perhaps more "modern" television-worthy form of female homosexuality than the cochona. At the same time the focus group demonstrated that young female viewers were able to equate Vicki's sexual subjectivity, as a "lesbian," with that of the "gay girl who dressed like a guy" of their past experience. The focus group viewers did not accept that a woman "liking women" is normal. But Vicki's femininity and subscription to Nicaraguan values of well-groomed girlishness create a performance of gender that appears normal even when her sexuality is not.

Like Angel, Vicki does not suit the neighborhood norm or the stereotypes associated with cochonas in Nicaragua. Of course, not all same-sex-attracted people in Nicaragua are masculine-appearing cochonas or flamboyant locas. However, those who possess these stereotypical and gender-transgressive qualities are the most "visible." Through televisionary tactics, the cochona and her male counterpart, 
the cochón, in their absence, are transformed into the lesbian and the homosexual. ${ }^{23}$ Sexto Sentido does make "visible" gay characters who conform to gender ideals who have been previously "invisible” in Nicaragua's public sphere. However, it leaves stigmatized queer characters - the cochona and the cochón-literally, out.

\section{ENGENDERING A CERTAIN FAME}

As the episodes have unfolded, Vicki's character has become more multifaceted. Viewing audiences have found out that, in addition to being a lesbian, Vicki is a recovering alcoholic. She is also, we find out, a survivor of sexual abuse. These two elements of her character, coupled with the fact that she is the show's lesbian representative, are touchy territory. Homosexuality, according to popularly held beliefs in Nicaragua, is often thought to be caused by childhood sexual abuse. It is also not uncommon for people to pathologize homosexuality, somewhat similar to alcoholism, as a sickness. For the scriptwriters, and from the point of view of social transformation, it was decided that Vicki ought to embody some of these stereotypes to create a space in the plot where they can then be eschewed. ${ }^{24}$ In the final iteration of Vicki, she is all three: lesbian, sexual abuse survivor, and recovering alcoholic. There was also some pondering on the part of the plot makers about Vicki's love life. Should she have a girlfriend on the show? If so, how should that girlfriend behave, and how should she look? Martina, one of a team of authors for Sexto scripts, explained that “we don't know if Vicki should have a feminine girlfriend to break the stereotypes or whether she should have a more masculine girlfriend." If Vicki were to have a female partner who is "less feminine" in appearance than she, this would reinforce a commonly held belief: only femininas (or muy mujeres or "women") couple with cochonas (dykes) — a demand that masculinity and femininity require their romantic foils. Although the question of Vicki's girlfriend would wait for a future episode, these "sexual scripts" (Gagnon 2004) intend to both challenge and play on cultural values, stereotypes, and assumptions. ${ }^{25}$

However, a script is never complete until it is performed. For the actresses themselves, one who plays a lesbian in the midst of coming out, the other the potential romantic interest of a lesbian, what were the stakes surrounding such performances, or were there any at all? I asked Norelí, who plays the role of Alejandra, if anyone had said anything about the homoerotic tensions on the show. She explained that at a recent youth workshop in which she participated, there were some questions: 
We were asked, Why is it necessary to have someone, if there was already Angel, who is homosexual, why do we have to have a lesbian? What was our interest, specifically, to reinforce this issue, about sexual options? One person said that it was nice (linda). And that the lesbian character was linda (nice, pretty) and very attractive (guapísima), and they asked me about this. Ah, in the first episode when Vicki appeared, someone wrote an e-mail and said that it wasn't believable that Alejandra has a relationship with a (young) lesbian woman. It wasn't possible that Alejandra would have an aventura (loosely, "fling") with a lesbian girl.

I think that when, in the later episode, it's a little more clear ... but now it's going to become more and more clear, and there are people who don't want Vicki to be a lesbian because she looks like a really feminine young woman (chavala), very pretty and all of that.

For Jacinta, who plays Vicki, I wondered what she initially thought when, after going to the audition, she was told the character she would be playing would be a lesbian. Her narrative, like the ideological aspirations of the show's producers, follows a pedagogical curve where new identity forms are meant to challenge older conventions around sexuality and gender. She showed a lot of enthusiasm about this process, both personally and politically:

I liked it! [She laughs.] Because it made me really happy . . . because to break with all the normal stuff. This is something that I had never done, and I was interested in doing it as a goal, yes, as a personal goal. For me to break my own prejudices and to do something public like this and to go out in the street and say, look, this is the work. Watch it. Analyze it. Take in the message, and if you can't do that, at least take away something. And so this is what made me really excited about doing it. If I had been some other way, then maybe not, maybe I wouldn't have been so interested in it.

And, commentaries, yes, we're going to see those. From the people, here in Nicaragua, on TV, these lesbian or gay roles are difficult. And the people take it like this: [she exhales loudly, exaggerated, throws her hands up, mocking a reaction of being scandalized], "This girl is a dyke or I don't know what!" But it also so happens, on the flip side, that this is positive, because people are learning, with these little details and examples, about how to handle this. 
As the performances of Angel and Vicki illustrate, those aspiring to reshape culture through media have employed strategies that opt for a particular "normalization" of homosexual subjects. Rather than depicting the cochón or the cochona, they have instead embraced "lesbian" and "homosexual" (or "gay") subjects. In their gendered mannerisms, commitment to monogamy, and aspirations to social success, lesbian, gay, and homosexual subjects that appear in these televisionary approaches are produced to suit heterosexual norms and broader Nicaraguan values. This is not gender subversion per se but, rather, the conscious retention of markers of masculinity and femininity, aiming to trouble the Nicaraguan body politic with novel sexual subjects. Whereas these sexual paradigms are certainly familiar from the vantage point of the United States and Europe, advocates also intend to create homosexual characters and gender performances that fade, blend, or segue into a "palatable" configuration for the Nicaraguan populace. This is a strategy of "normalizing" (Warner 1999) the queer subject, but with a notion of Nicaraguan-ness or "pura Nicaragüense” in mind. (See Figure 3.)

\section{ADVOCACY IN TELEVISIONARY TIMES}

It has become increasingly important to Nicaraguan advocates to produce particular images of sexuality and gender in the performative and entertainment venue of television. In a place where the state and church are invested in quelling both sexual rights (with antisodomy laws) and gender activism (by repealing abortion provisions), there may be a certain urgency for these forms of advocacy media. I have suggested these techniques are "televisionary." These interventions diverge from more classic activist projects in Nicaragua that center on programmatic policy change. Instead, they aim to shift cultural values with their media messages. Technological interventions such as these are not a perfect solution to activist dilemmas, an "artful guerilla media war" (Alvarez et al. 1998:7) that will undo all injustices, although they sometimes appear to have this potential (Rabasa 1997). Although they negotiate the state by facilitating cultural change through entertainment rather than legislation, televisionary tactics are nonetheless intertwined with state processes. These forms of media activism have proliferated and, as Nicaraguan advocates assert, grown precisely because of state coercion, in particular the antisodomy law. Characterizing reproductive choice and sexual identity in the ways that televsionary advocacy does offers a challenge to state policy through the images and discussion it proliferates. These interventions project putatively private desires (such as homoerotics) and socially sensitive moral matters (such as Sofía's choice) into Nicaragua's public sphere despite legislative moves to the contrary. Because they have 


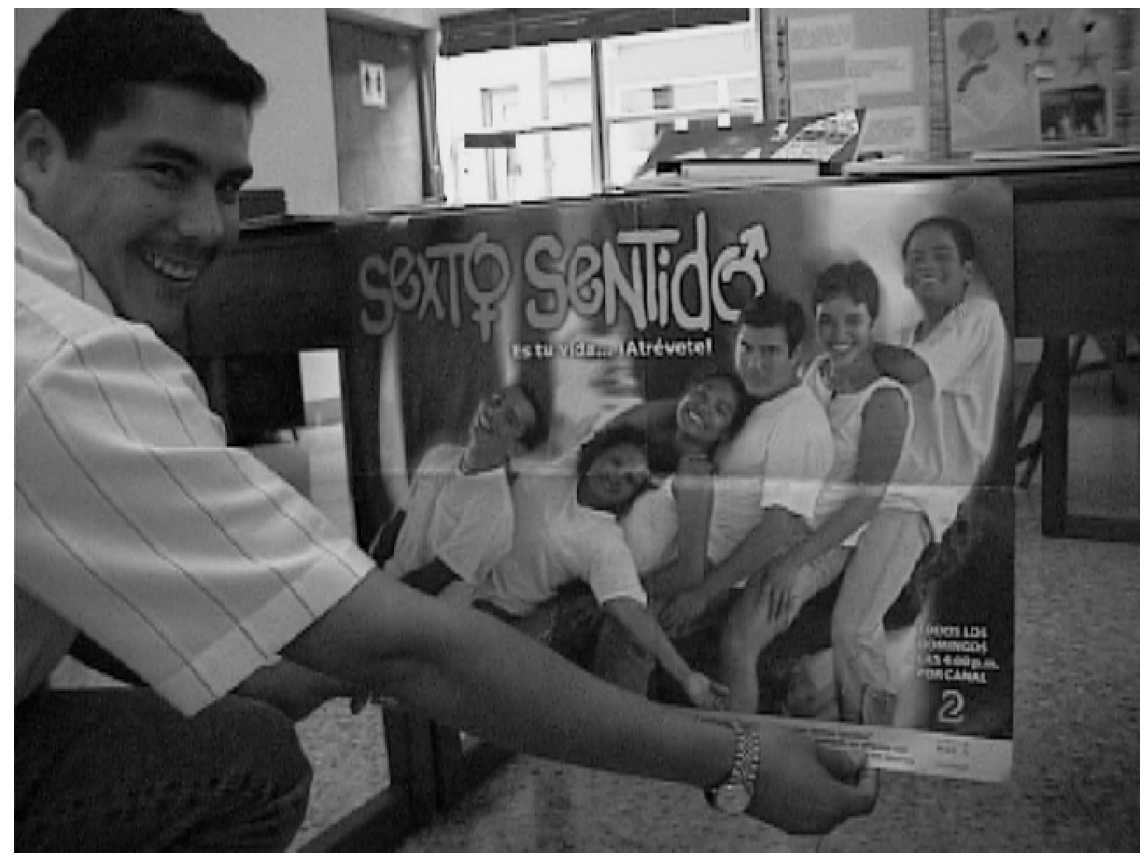

FIGURE 3. The actor who plays Angel, the TV program's gay male character, holds a promotional poster featuring the show's central cast. Angel mirrors "egalitarian" and "appropriate" performances of gender that are familiar in an international register but which diverge from Nicaragua's more autochthonous cochón (fag). The only dramatic television series to be produced in Nicaragua, Sexto Sentido combines very familiar scenes and colloquial expressions to promote a sense of the "local" while at the same time transmitting "global" iterations of subjectivity, identity, and progressive politics. Photo by Cymene Howe.

effectively gone beyond the state and the street, they are an example of the at-once political and cultural possibilities that have been of interest to theorists of new social movements (Alvarez et al. 1998; Fox and Starn 1997; Warren 1998). These forms of cultural activism may not make the same sorts of radical claims as other historical moments, but they do suggest shifts in how social transformation may be approached.

Media operates in powerful and effective ways as it articulates, and plays between, the local and the global in these advocacy projects. Televisionary tactics that seek to redefine Hollywood homosexualities and filmic feminisms draw very explicitly from the global sphere and propagate carefully constructed images of sexual and gendered subjects. Although televisionary tactics draw from global discourses and technologies, they are also readily exportable and cross borders with ease. Communications technologies, television, radio, the Internet, and cellular phone services now permeate the Latin American urban milieu, giving them immense 
socially strategic potential and making "activism at a distance" more possible (Ribiero 1998:325-342). Sexto Sentido, for example, has found a wider viewing audience across Central America and, most recently, the United States. ${ }^{26}$ It was also the subject of a documentary that screened all over the world and is now available online through the NGO's website for a global audience to view at will. ${ }^{27}$ Nicaraguan advocates do borrow, and transform, tactics and discourses from global circuits. But the televisionary products that advocates create are also readily disseminated in this same global sphere.

Televisionary approaches generate a forum for sexual and reproductive rights as well as identities and practices, but the success of these screenings has relied on performances privileging particular kinds of sexual subjects: fictional gay men "beyond reproach" and very "feminine" lesbians. Those who star in socially responsible telenovelas can claim, "I am not a real lesbian, I only play one on TV." The formulation of a gay man, as (an) Angel, and the feminine trappings of Vicki, as well as back-alley rapes and private clinic remedies, intend a political and intentionally crafted preferred reading (Hall 1997a, 1997b). The didactic dimensions, as well as the impetus to entertain, suggest that representations of sexuality and gender on Nicaraguan television share a kinship with internationally recognizable lesbian and gay subjects and feminist projects. Here, homosexual subjects are carefully coiffed in a dramatic process of normalizing homosexuality — and gay men and lesbians are crafted to meet almost Weberian ideal types of monogamy, gender conformity, and social success - even when obtaining these sorts of successes may be the exception in Nicaragua, for both straight and gay people. But there is also a negotiated position between the putatively local and global, where locality is consciously produced among and between multivalent categories of sexuality (cochones or gays) and socioeconomic class markers (such as diamond engagement rings and private clinics), marking these politics with an internationally recognizable "distinction."

Televisionary tactics reflect the polyamorous wedding of neoliberal, global, and postmodern phenomena. The conversation I described at the beginning of this article, where the director of USAID in Managua described the television show as "a model" for development in the Third World, may be particularly telling. The content (framing lesbian and gay identities and reproductive rights in positive terms) may, at times, conflict with the ideologies of the U.S. government, depending on the regime in power at any given time. However, I would argue that the "model" at work here does have a particular appeal: social engineering on a shoestring budget that appears to be an autochthonous representation of cultural values. From one perspective, televisionary activism is development on the cheap, especially 
when compared with large infrastructural projects: not dams, but DV cams; not well-paid engineers, but low-salaried local actors. But televisionary activism also fulfils a democratizing impulse. It appears to emphasize local or "indigenous" social interventions conceived and executed by Nicaraguan nationals rather than First World development experts and technocrats. ${ }^{28}$ Programs that appear to be "pura Nicaragüense" appeal to liberal visions of less imperially laden development, performed as local, by "locals," in ways that fit very neatly with Western notions of cultural autonomy. These inexpensively produced, transnationally distributable, and charmingly local approaches that seek to shift social values must seem, from the point of view of international development agencies, to be exceptionally well suited to neoliberal development desires: an offshoring of social justice, where the production of "locality" becomes a highly effective means for marketing globally circulated politics of sex and gender as well as democratic and liberal value regimes regarding choice, subjectivity, and identity.

Programming aesthetics may be shaped with local populations in mind, but clearly they have transnational appeals as well: using internationally recognizable paradigms of sexuality and gender that function to both "sell" these identities in Nicaragua and elsewhere and at the same time ensure the show's marketability, or social justice viability, internationally. Put in other terms, this ambivalent doubling places value on the "local" as it sells social justice television, which in turn mimetically reproduces the transnational phenomena of "gay" and "lesbian" identities in a place where these particular monikers, signs, or identificatory practices have only recently appeared. What is revealed in this process is the slipperiness of signs signaling "local," exposing the ruse of authenticity and simultaneously demonstrating how effectively locality, in mediated form, functions to convey particular transnational value systems. Studies of globalization and cultural "flows" have attempted to account for the dynamics of a media-saturated world, wondering how to understand the local as distinct from the global or whether this is even possible. Media may indeed enjoy an "overdetermined" location in discourses of globalization (Hardt and Negri 2001; Jameson 1991). But, as numerous authors have demonstrated, the nation-state continues to be central to the way media and its (at times) anxiety-producing effects are conceptualized (Abu-Lughod 2002, 2004; Boellstorff 2003a, 2003b; Dávila 2001; La Pastina 2004; Mankekar 1999; Mazzarella 2003; Miller 1998). If, in the context of globalization, there has been a return to ferreting out and valorizing the "local" in the midst of globalization through a "resurgence of the local" or "hybridity," then there have also been concomitant moves toward reifying local culture qua local with an "aura of authenticity" (Mazzarella 
2004:347). Following Marshall McLuhan's (1964) now well-disseminated notion that "the medium is the message," it is clear that media conveys more than technical acumen and social priorities (Williams 1974). It is not only media content that conveys a "message" but also the medium's localness, its embedded and familiar origin story, that lends weight to programs such as Sexto Sentido or other social justice media interventions. In this intimate framework local knowledge is particularly prized and media projects are assured relevance because of their "authentic localness. ${ }^{29}$ Nicaraguan televisionary interventions depend on their ability to speak in the registers - linguistic, visual, cultural, and political — relevant to the local and national context. The local is valorized. But at the same time globally recognizable gay characters and feminist concerns are screened for all to see.

\begin{abstract}
This article develops the concept of "televisionary" activism — a mediated form of social justice messaging that attempts to transform culture. Focusing on a locally produced and very popular television show in Nicaragua, I consider how social justice knowledge is produced through television characters' scripting and performance. The ideological underpinnings aspire to a dialogic engagement with the audience, as producers aim to both generate public discourse and benefit from audiences' suggestions and active engagement. Several levels of media advocacy interventions are considered including the production, scripting, and translation of transnational material into local registers. Televisionary activism offers challenges to several conservative social values in Nicaragua by placing topics such as abortion, domestic violence, sexual abuse, homosexuality, and lesbianism very explicitly into the public sphere. At the same time, sexual subjects on the small screen must be framed in particular ways, as, for instance, with the homosexual subjects who are carefully coiffed in normalized human dramas. Finally, many of these televisionary tactics draw from and engage with transnational tropes of identity politics, and "gay" and "lesbian" subjectivity in particular, confounding the relationship between real and idealized sexual subjects in Nicaragua. That is, these televisionary tactics "market" transnational identity politics but derive legitimacy through their very "localness."
\end{abstract}

Keywords: media, activism, sexuality, public culture

\title{
NOTES
}

Acknowledgments. I extend many thanks to the staff at Puntos de Encuentro in Managua for their friendship, for their generosity with their time, and for providing access to the production aspects of the television show. This article has benefited from comments by Kim Fortun; three anonymous reviewers for Cultural Anthropology; the 2005-07 Mellon Seminar participants at Cornell University; and audiences at the Universities of Washington, Buffalo, and Oklahoma. Funding for the research was provided by the Fulbright Foundation. 
1. The heading "The Revolution Will Be Televised" is indebted to, and an inverted version of, the title of the song “The Revolution Will Not Be Televised," written by Gil Scott Heron in 1970 and covered most famously by The Last Poets in 1971. The Last Poets are often credited as the original rap band, with their overtly political lyrics, challenging white racial hegemony and capitalist consumerism and commercialization. The song itself is also one of the signature anthems of the U.S. Black Power movement. Here I evoke the song to suggest a different moment in movement politics, where television has indeed become instrumental in the work of gender and sexuality advocates in contemporary Nicaragua, as elsewhere.

2. All personal names have been changed to protect the identities of individuals.

3. For instance, The Bird Cage, starring Robin Williams, screened at least five times on Nicaraguan cable TV in six months (April-September 2001). Clear exceptions to the dearth of shows featuring lesbians on U.S. television more recently are The L Word and Ellen, neither of which screen in Nicaragua.

4. One Sunday afternoon after I volunteered to buy bottles of cold Coke for everyone assembled around the household TV, I was able to listen to the plot of Sexto Sentido unfold, in Doppler effect, as the dialogue leaked from the ever-open windows and doors of each house I passed on my way to the corner pulperia (convenience store) in a working-class neighborhood in Managua. I took this as further testament to the show's popularity, if unscientific in its method.

5. This position mirrors some of the theoretical discussion surrounding "alternative," "radical," and "mainstream" media as uneasily separable entities (see Atton 2002; Downing 1984; Rodríguez 2001).

6. Cochones and cochonas are largely marked both by their gender transgressions (demonstrations of femininity or masculinity considered to be inappropriate) and by their sexual behavior with others of the same sex. However, the same-sex romantic partners of cochonas or cochones, who are often "gender appropriate" (masculine men and feminine women), have historically elided stigma as homosexual. Roger Lancaster (1992) has also made important distinctions between the relative honor of being the "subject" (inserter or "dominant") partner in malemale sexual encounters and the shame associated with being, instead, the "object" (insertee or "passive") partner. Little primary research has been done with women designated as cochonas in Nicaragua (cf. Bolt González 1996; Van Gisel n.d.), so it is not possible to say exactly how women configure in this (contested) passive-active paradigm, making more research necessary.

7. I use the term advocates throughout this article to designate those who are involved in the struggles for sexuality and reproductive rights in Nicaragua. Some of these advocates are NGO professionals, and others are "grassroots" activists who engage in street protests, convene discussion groups, and organize campaigns to promote visibility for sexual and gender rights. I intentionally avoid creating a sharp distinction between paid "advocates" and "grassroots activists," for it seems to me that to do so is to dismiss the deeply held convictions that professional advocates consistently bring to their social justice work.

8. Televisionary activism, as I am conceiving it, is distinct from James Weiner's (1997) critique of "televisualist" anthropology as an ontologically Western and semiotically loaded analytic. As I will sketch here, it is not clear in the case of Nicaragua whether these advocacy practices are so much "self-representative" as they are aimed at drawing from global flows of rights messages and identities that circulate, now, virtually everywhere. Rather than "cultural revival" or self-representation practices discussed by Ginsburg (1993) and Turner (1992), among others, televisionary advocacy in the case of Nicaragua is less concerned with how advocates are representing them-"selves" (or Nicaraguans more generally) and more concerned with how they are representing global discourses and political praxis.

9. Televisionary activism is one component of more extensive gender and sexuality movements, NGOs, and cultural politics in contemporary Nicaragua, the subject of the larger research project (1999-2006) about advocacy networks from which this analysis is drawn (Howe in press).

10. Theorizing mass media has been a tendentious project in the social sciences and humanities, and only relatively recently has the media become part of anthropological attempts to understand these forms of knowledge and practice. The Frankfurt School, most famously 
through Theodor Adorno, has warned against mass media as a tool of "mass deception" likely to "fetter consciousness" (Adorno 1997:29) and render the public supplicants to a grand ideological regime. Later interventions concerning audiences' interpretations of media messages, particularly through British cultural studies, argue that although mass media may have a "preferred reading" (Hall 1997b) — a set of intended values or messages - they are not unproblematically or uniformly understood. Rather, mass media could be viewed as an active social practice where cultural hegemony is challenged and resistance is enacted (Hall 1997) by a socially constituted audience (Ang 1995). Following the interventions of Hall and others on how media images and messages are received and interpreted, a spate of "reception studies" followed (Ang 1995; Liebes and Katz 1994), as well as ethnographic accounts of "fan cultures" (Jenkins 2006a). However, audience reception and its association with cultural transformation have been a difficult analytic object.

11. To further underscore the circulation, rather than a one-way dissemination, of media productions in the present, it is worth pointing out that since this time Betty La Fea has become a network television show in the United States, Ugly Betty, which won a Golden Globe award in 2007. Betty La Fea did generate a set of pop cultural phenomena in Nicaragua in its own right: Betty T-shirts were created and sold in Managua's municipal market, and the previous night's episode was always the talk of the town. There was a Betty look-alike pageant in Managua that was featured in the national newspaper, El Nuevo Diario. Seeking a perfect simulacrum of Betty, trasvesti (biological men dressed in women's clothing) donned Betty-wear and mimicked her perplexed, earnest ambition.

12. This commentary mirrors similar discussions in the United States, for example, regarding the "mainstreaming" of gays and lesbians in popular culture and television and advertising in particular. Here too, the question is often whether particular representations of gays and lesbians are beneficial or unhelpful within larger campaigns to establish sexuality equality (Vaid 1995; Warner 1999). I should also point out that this comment about the visibility of gay characters on Nicaraguan television came from a well-known advocate for lesbian and gay rights in Nicaragua. He was not advancing the notion that there should be less representation of homosexuality on television.

13. Nicaraguan men who have sex with other men as the "passive" or "feminized" partner are called, colloquially and with derogatory underpinnings, cochones. Cochones are also often described as mano quebrada (broken handed), which better translates to "broken wristed." To demonstrate this concept, one afternoon while we were talking, Ernesto (a longtime homosexual rights activist) rose from his chair and affected a hip-swishing swagger. He held his hand at chest level, with a bent wrist, something like a damsel holding a handkerchief, and explained, "This is how the cochones are."

14. The funding agencies and programs that provided financial support for the show are Novib Agencia Sueca para el Desarrollo Internacional, Hivos, Instituto Austriaco Norte Sur, the Summit Foundation, the Moriah Fund, Shaler Adams Foundation, USAID, and the Ford Foundation.

15. The use of USAID funds might suggest cultural imperialism at work. However, advocates consistently insist that although their work is supported by foreign funding, its content is not influenced by it. This is questionable of course. Where influence may be more apparent is in the fact that, in addition to several Nicaraguan scriptwriters and advisers, there are foreignborn (although often nationalized) advocates from other South, Central, and North American countries as well as Europe who contribute ideas and sometimes dialogue and narrative for the television show. My concern here is not with the imperial implications of funding but, rather, the more subtle influence and appearance of sexual identities and reproductive politics in these media spaces.

16. Movie and television stars are associated, in the first instance, with Hollywood and the U.S. film and television industry. However, the notion of the "star" has traveled far beyond Hollywood. In the context of Nicaragua, these actors are seen as celebrities: they are often recognized on the street, asked for autographs, and at the center of much attention particularly from youth. 
17. The concept of "edutainment" was arguably made most famous by the advent of Sesame Street in 1969 in the United States. Combining lessons with entertainment, this mode of representation has become a multibillion-dollar industry in the United States as a commercial and pedagogical endeavor. In the Nicaraguan case, there is less commercial value to the televisionary projects that advocates carry out, although in principle, the ways in which entertainment is meshed with pedagogical and dialogic imperative are similar (Barnett 1999; Buckingham and Scanlon 2005).

18. Franky, the only character to have an abortion, also became pregnant through no "fault" of her own, other than having the indiscretion to walk down a dark street in a place where it is notoriously not safe to do so. Franky's pregnancy did not come through any carnal practices of her own; she is a certifiable victim (Brown 1995, 2005). From the point of view of more socially conservative viewers, Franky's abortion might have appeared to be a more warranted legal or "moral" transgression.

19. The character Maude, played by Bea Arthur on Norman Lear's politically progressive television show of the same name, chose to have an abortion two months prior to Roe v. Wade in 1972. Since then, network television has studiously avoided abortion as too controversial an act for a character to carry out, although debating the topic is possible in more politically situated television programming such as The West Wing. Cable television has been more daring, with Six Feet Under's character Claire opting for an abortion. The short-lived WB show Jack and Bobby does have a female protagonist (Missy) who chooses to have an abortion, although she dies a violent death in the ensuing episode. The distinction of Maude's choice is that no apparent "punishment" followed.

20. This is foreshadowed earlier when Sofía has a job interview at a human rights organization, and Gabriel taunts her, "Human rights, I got better things to do, like washing underwear!" Gabriel means this facetiously, as though he would rather do anything, even the "cochón-like" task of washing underwear, than undertake human rights work. This plotline provides a narrative where Gabriel can "grow and transform" through the process of self-realization that the producers outline.

21. Within the first episodes, there are several references to Angel's homosexuality beyond those described above. He explains to one friend, "I've had a lot of girlfriends, but they didn't 'move the floor' (mueve el piso [do it, rock my world]) for me. But with him [Christian], it's different." As Angel is about to tell Eddy, the only member of the group to whom he has not come out, that "Christian" is not a woman, Eddy suddenly falls fast asleep, and Angel has missed his chance.

22. Several works theorizing and ethnographically charting the phenomenon of the transnational circulation of lesbian and gay identity paradigms and practices demonstrate the uneven ways in which sexuality is taken up and lived as a category of meaning and experience (see Altman 2001; Boellstorff 2003a, 2003b; Carrillo 2002; Gopinath 1998; Howe 2002; Manalansan 1997; Martin 2000; Patel 2004; Povinelli and Chauncey 1999; Quiroga 2000; Rofel 2007; Sang 2003). Martin Manalansan (1997) makes a compelling argument that the implicit values of modernity and development that are embodied in the model of the "global gay" work to position homosexual persons and practices in the global South as somehow evolutionarily "behind" a putatively more "egalitarian" and out lesbian or gay subject.

23. The cochoneros or hombre hombres who may have sex with cochones but retain their macho status, or the feminine-appearing women (femeninas) who sleep with other women but are considered "real women" who just "hang around" with dykes, are likewise not represented in these media tactics. A productive parallel might be made here with similar discussions of butch or femme visibility in U.S. lesbian and gay communities (Halberstam 1998; Kennedy and Davis 1993; Nestle 1992), as well as the politics of gender performance (Butler 1990, 1993; Case et al. 1995).

24. One might also argue that the show is reproducing stereotypes surrounding rape (the fault lies with those girls who are foolish enough to wander down dark allies) and lesbianism (brought about by childhood sexual abuse). However, the way in which these issues are resolved - in the case of Franky, having an abortion and overcoming these crises with friends' support or, in the case of Vicki, disclosure, self-confidence, and explicit engagement with 
past abuse and her alcoholism as an escape from this abuse - suggests that the producers and screenwriters seek to confront the most pernicious stereotypes through the plot narrative, resolving the dilemmas they present. It is precisely with the intent of reversing and reframing these stereotypes that the show creates the performances it does. Whether in the long durée this approach will transform Nicaraguans' perceptions and transform these particular stereotypes remains untested.

25. John Gagnon's “sexual script” takes a page from Erving Goffman's work, although in a psychological-developmental framework, suggesting that sexual interactions are socially organized through various stages of scripting (according to age and cultural location) and actors apprehend their "lines" and "roles" as if they were performers onstage.

26. As the producers had hoped in their original proposal, the show began screening in other Central American countries and Mexico. In mid-June 2007 Sexto Sentido was scheduled to begin screening in the United States through DirecTV.

27. The program was the subject of a documentary, Novela, Novela, directed and produced by Liz Miller (2002). Novela, Novela received awards and was screened internationally at lesbian and gay film festivals to much acclaim (Liz Miller, personal communication, April 15, 2001).

28. It is worth noting that the organization that produces the television show in Nicaragua is not made up of solely Nicaraguan nationals. However, rather than belabor the point of how "Nicaraguan" these interlocutors are (given their substantial time in country, this is a very arguable distinction), I intend to emphasize here that the show seeks to appear very "Nicaraguan," vis-à-vis the discourses and images used.

29. Media scholars have likewise described a phenomenon that they term "cultural proximity" or, more recently, multiple "proximities" linked to the desire for media products that resonate with one's own language, culture, history, and values — or at least understood as recognizably similar within a larger context of global flows (La Pastina and Straubhaar 2005).

Editor's Note. In the past, Cultural Anthropology has published many articles on gender and sexuality. See, for example, Katherine Pratt Ewing's (2006) article on cinema and social work among diasporic Turkish women; Deborah A. Elliston's (2000) article on "the geographies of gender and politics" with reference to Polynesian nationalism; and Corinne P. Hayden's (1995) article on "gender, genetics, and generation" in the context of lesbian kinship. Cultural Anthropology has also published a range of articles on activist media. See, for example, Henry Jenkins's (2006b) article on the politics of dislocation; Arlene Dávila's (1999) article on art, museums, and "the politics of multicultural encompassment”; and Michael M. J. Fischer's (1991) article on "visual-virtual realities and post-trauma polities."

\section{REFERENCES CITED}

Abu-Lughod, Lila

2002 Egyptian Melodrama - Technology of the Modern Subject? In Media Worlds: Anthropology on New Terrain. Faye D. Ginsburg, Lila Abu-Lughod, and Brian Larkin, eds. Pp. 115-133. Berkeley: University of California Press.

2004 Dramas of Nationhood: The Politics of Television in Egypt. Chicago: University of Chicago Press.

Adorno, Theodor

1997 Culture Industry Reconsidered. In Media Studies: A Reader. Paul Marris and Sue Altman, Dennis Thorham, eds. Pp. 24-29. Edinburgh: Edinburgh University Press.

2001 Global Sex. Chicago: University of Chicago Press.

Alvarez, Sonia, Evelina Dagnino, and Arturo Escobar, eds.

1998 Cultures of Politics/Politics of Cultures: Re-Visioning Latin American Social Movements. Boulder: Westview Press. 
Amnesty International

2004 Nicaragua Report. Electronic document, http://web.amnesty.org/report2004/ nic-summary-eng, accessed September 1, 2006.

Anderson, Benedict

1983 Imagined Communities: Reflections on the Origins and Spread of Nationalism. New York: Verso Books.

Ang, Ien

1995 Living Room Wars: Rethinking Media for a Postmodern World. London: Routledge.

Appadurai, Arjun

1996 Modernity at Large: Cultural Dimensions of Globalization. Minneapolis: University of Minnesota Press.

Appadurai, Arjun, and Carol Breckenridge

1988 Why Public Culture? Public Culture 1(1):5-9.

Askew, Kelly

2002 Introduction. In The Anthropology of Media: A Reader. Kelly Askew and Richard R. Wilk, eds. Pp. 1-14. Oxford: Blackwell.

Atton, Chris

2002 Alternative Media. London: Sage.

Babb, Florence

2003 Out in Nicaragua: Local and Transnational Desires after the Revolution. Cultural Anthropology 18(3):304-332.

Barnett, Clive

1999 The Limits of Media Democratization in South Africa: Politics, Privatization and Regulation. Media, Culture and Society 21(5):649-671.

Berry, Chris, Fran Martin, and Audrey Yue, eds.

2003 Mobile Cultures: New Media in Queer Asia. Durham, NC: Duke University Press. Boellstorff, Tom

2003a Dubbing Culture: Indonesian Gay and Lesbi Subjectivities and Ethnography in an Already Globalized World. American Ethnologist 30(2):225-242.

2003b I Knew It Was Me: Mass Media, “Globalization,” and Lesbian and Gay Indonesians. In Mobile Cultures: New Media in Queer Asia. Chris Berry, Fran Martin, and Audrey Yue, eds. Pp. 21-51. Durham, NC: Duke University Press.

Bolt González, Mary

1996 Sencillamente Diferentes: La autoestima de las mujeres lesbianas en los sectores urbanos de Nicaragua. Managua, Nicaragua: Fundación Xochiquetzal.

Boyer, Dominic

2005 Spirit and System: Media, Intellectuals, and the Dialectic in Modern German Culture. Chicago: University of Chicago Press.

2007 Understanding Media: A Popular Philosophy. Chicago: Prickly Paradigm Press. Buchsbaum, Jonathan

2003 Cinema and the Sandinistas: Filmmaking in Revolutionary Nicaragua. Austin: University of Texas Press.

Buckingham, David, and Margaret Scanlon

2005 Selling Learning: Towards a Political Economy of Edutainment Media. Media, Culture and Society 27(1):41-58.

Brown, Wendy

1995 States of Injury: Power and Freedom in Late Modernity. Princeton: Princeton University Press.

2005 Edgework: Critical Essays on Knowledge and Politics. Princeton: Princeton University Press. 
Butler, Judith

1990 Gender Trouble: Feminism and the Subversion of Identity. New York: Routledge.

1993 Bodies That Matter: On the Discursive Limits of "Sex.” New York: Routledge.

Carrier, Joseph

1995 De los otros. New York: Columbia University Press.

Carrillo, Héctor

2002 The Night Is Young: Sexuality in Mexico in the Time of AIDS. Chicago: University of Chicago Press.

Case, Sue Ellen, Susan Leigh Foster, and Philip Brett, eds.

1995 Cruising the Performative: Interventions into the Representation of Ethnicity, Nationality and Sexuality. Indianapolis: University of Indiana Press.

Chanan, Michael

2004 Cuban Cinema. Minneapolis: University of Minnesota Press.

Dávila, Arlene

1999 Latinizing Culture: Art, Museums, and the Politics of U.S. Multicultural Encompassment. Cultural Anthropology 14(2):180-202.

2001 Latinos, Inc: The Marketing and Making of a People. Berkeley: University of California Press.

Debord, Guy

1995 [1967] The Society of the Spectacle. Donald Nicholson-Smith, trans. New York: Zone Books.

Donham, Donald D.

1998 Freeing South Africa: The "Modernization" of Male-Male Sexuality in Soweto. Cultural Anthropology 13(1):3-21.

Downing, John

1984 Radical Media: The Political Experience of Alternative Communication. Boston: South End.

1987 Film and Politics in the Third World. New York: Praeger.

2001 Radical Media: Rebellious Communication and Social Movements. London: Sage. Elliston, Deborah A.

2000 Geographies of Gender and Politics: The Place of Difference in Polynesian Nationalism. Cultural Anthropology 15(2):171-216.

Ewing, Katherine Pratt

2006 Between Cinema and Social Work: Diasporic Turkish Women and the (Dis)Pleasures of Hybridity. Cultural Anthropology 21(2):265-294.

Field, Les W.

1999 The Grimace of Macho Ratón: Artisans, Identity and Nation in Late-TwentiethCentury Western Nicaragua. Durham, NC: Duke University Press.

Fischer, Michael M. J.

1991 Anthropology as Cultural Critique: Inserts for the 1990s Cultural Studies of Science, Visual-Virtual Realities, and Post-Trauma Polities. Cultural Anthropology 6(4):525-537.

Fox, Richard G., and Orin Starn, eds.

1997 Between Resistance and Revolution: Cultural Politics and Social Protest. New Brunswick, NJ: Rutgers University Press.

Franco, Irma, Róger Olivas, and Melvin Martinez

2006 Otra embarazada bajo grave riesgo. El Nuevo Diario, November 9. Electronic

Freire, Paulo document, http:/ /www.elnuevodiario.com.ni, accessed December 22, 2006.

1973 Pedagogy of the Oppressed. New York: Seabury Press. 
Friedman, Sara L.

2006 Watching Twin Bracelets in China: The Role of Spectatorship and Identification in an Ethnographic Analysis of Film Reception. Cultural Anthropology 21(4):603-632. Gagnon, John H.

2004 An Interpretation of Desire: Essays in the Study of Sexuality. Chicago: University of Chicago Press.

Galeano, Luis

2003 Rosa, embarazo y aborto con 9 años. Cronica 384 (February 23). Electronic document, http: //www.elmundo.es/cronica, accessed December 18, 2006.

Ganti, Tejaswini

2002 "And Yet My Heart Is Still Indian": The Bombay Film Industry and the (H)Indianization of Hollywood. In Media Worlds: Anthropology on New Terrain. Faye D. Ginsburg, Lila Abu-Lughod, and Brian Larkin, eds. Pp. 281-300. Berkeley: University of California Press.

Ginsburg, Faye

1993 Aboriginal Media and the Australian Imaginary. Theme issue, "Screening Politics in a World of Nations," Public Culture 5(3):557-578.

Gopinath, Gayatri

1998 On Fire. GLQ: A Journal of Lesbian and Gay Studies 4(4):631-636.

Habermas, Jürgen

1992 The Structural Transformation of the Public Sphere. New York: Polity Press.

Halberstam, Judith

1998 Female Masculinity. Durham, NC: Duke University Press.

Hall, Stuart S.

1997a The Centrality of Culture: Notes on the Cultural Revolutions of Our Time. In Media and Cultural Regulation. K Thompson, ed. Pp. 208-238. London: Sage Press.

1997b The Work of Representation. In Representation: Cultural Representation and Signifying Practices. S. Hall, ed. Pp. 13-74. London: Sage.

Hardt, Michael, and Antonio Negri

2001 Empire. Cambridge, MA: Harvard University Press.

Harvey, David

1990 The Condition of Postmodernity: An Inquiry into the Origins of Cultural Change. Oxford: Blackwell Publishers.

Hayden, Corinne P.

1995 Gender, Genetics, and Generation: Reformulating Biology in Lesbian Kinship. Cultural Anthropology 10(1):41-63.

Howe, Cymene

2002 Undressing the Universal Queer Subject: Nicaraguan Activism and Transnational Identity. City and Society 14(2):237-279.

In press Sexual Sovereignty: Mediating Gender and Sexuality in Nicaragua. Durham, NC: Duke University Press.

Jameson, Frederic

1991 Postmodernism, or, the Cultural Logic of Late Capitalism. Durham, NC: Duke University Press.

Jenkins, Henry

2006a Fans, Bloggers and Gamers: Media Consumers in a Digital Age. New York: New York University Press.

2006b "People from That Part of the World": The Politics of Dislocation. Cultural Anthropology 21(3):469-486. 
Juarez Ordoñez, Lester

2003 Demandan aborto para salvar niña embarazada. El Nuevo Diario, February 19. Electronic document, http://www.elnuevodiario.com.ni, accessed December $18,2006$.

Kampwirth, Karen

2004 Feminism and the Legacy of Revolution: Nicaragua, El Salvador, Chiapas. Athens: Center for International Studies, Ohio University.

2006 Resisting the Feminist Threat: Antifeminist Politics in Post-Sandinista Nicaragua. NWSA Journal 18(2):73-101.

Kennedy, Elizabeth Lapovsky, and Madeline Davis

1993 Boots of Leather, Slippers of Gold: The History of a Lesbian Community. New York: Routledge.

Kipnis, Laura

1999 The Stepdaughters Story: Scandals National and Transnational. Social Text 58(Spring):59-73.

Kulick, Don

1998 Travesti: Sex, Gender, and Culture among Brazilian Transgendered Prostitutes. Chicago: University of Chicago Press.

Lancaster, Roger

1992 Life Is Hard: Machismo, Danger, and the Intimacy of Power in Nicaragua. Berkeley: University of California Press.

La Pastina, Antonio C.

2004 Telenovela Reception in Rural Brazil: Gendered Readings and Sexual Mores. Critical Studies in Media Communication 21(2):162-181.

La Pastina, Antonio C., and Joseph D. Straubhaar

2005 Multiple Proximities between Television Genres and Audiences: The Schism between Telenovelas' Global Distribution and Local Consumption. Gazette: International Journal for Communication Studies 67(3):271-288.

Liebes, Tamar, and Elihu Katz

1994 The Export of Meaning: Cross-Cultural Readings of Dallas. New York: Polity Press.

Lomnitz, Claudio

2001 Deep Mexico, Silent Mexico: An Anthropology of Nationalism. Minneapolis: University of Minnesota Press.

López, Ana M.

1995 Our Welcomed Guests: Telenovelas in Latin America. In To Be Continued ... Soap Operas around the World. Robert C. Allen, ed. Pp. 256-275. New York: Routledge.

Manalansan, Martin F., IV

1997 In the Shadow of Stonewall: Examining Gay Transnational Politics and the Diasporic Dilemma. In The Politics of Culture in the Shadow of Capital. Lisa Lowe and David Lloyd, eds. Pp. 485-505. Durham, NC: Duke University Press.

Mankekar, Purnima

1999 Screening Culture, Viewing Politics: An Ethnography of Television, Womanhood and Nation in Postcolonial India. Durham, NC: Duke University Press.

Martin, Fran

2000 Surface Tensions: Reading Productions of Tongzhi in Contemporary Taiwan. GLQ: A Journal of Lesbian and Gay Studies 6(1):61-86.

Martín-Barbero, Jesús

1995 Memory and Form in the Latin American Soap Opera. In To Be Continued ... Soap Operas around the World. Robert C. Allen, ed. Pp. 276-284. London: Routledge. 
Mazzarella, William

2003 Shoveling Smoke: Advertising and Globalization in Contemporary India. Durham, NC: Duke University Press.

2004 Culture, Globalization, Mediation. Annual Review of Anthropology 33:345-367. McLuhan, Marshall

1964 Understanding Media: The Extensions of Man. New York: McGraw Hill. Miller, Liz, dir.

2002 Novela, Novela. 30 min. New Haven, CT: Red Lizard Productions.

Miller, Toby

1998 Hollywood and the World. In The Oxford Guide to Film Studies. J. Hill and

Nestle, Joan

P. C. Gibson, eds. Pp. 371-382. New York: Oxford University Press.

1992 The Persistent Desire: A Femme-Butch Reader. New York: Alyson Press.

Parker, Richard

1998 Beneath the Equator: Cultures of Desire, Male Homosexuality, and Emerging Gay

Communities in Brazil. New York: Routledge.

Patel, Geeta

2004 Homely Housewives Run Amok: Lesbians in Marital Fixes. Public Culture 16(1):131-158.

Pedelty, Mark

1995 War Stories: The Culture of Foreign Correspondents. New York: Routledge.

Povinelli, Elizabeth, and George Chauncey

1999 Thinking Sexuality Transnationally: An Introduction. Special issue, "Thinking Sexuality Transnationally." GLQ: A Journal of Lesbian and Gay Studies 5(4):439450.

Priuer, Annick

1998 Mema's House, Mexico City: On Transvestites, Queens, and Machos. Chicago: University of Chicago Press.

Quiroga, José

2000 Tropics of Desire: Interventions from Queer Latino America. New York: New York University Press.

Rabasa, José

1997 Of Zapatismo: Reflections on the Folkloric and the Impossible in a Subaltern Insurrection. In The Politics of Culture in the Shadow of Capital. Lisa Lowe and David Lloyd, eds. Pp. 399-431. Durham, NC: Duke University Press.

Randall, Margaret

1993 To Change Our Own Reality and the World: A Conversation with Lesbians in Nicaragua. Signs 18(4):907-924.

Ribiero, Gustavo Lins

1998 Cybercultural Politics: Political Activism at a Distance in a Transnational World. In Cultures of Politics/Politics of Cultures: Re-Visioning Latin American Social Movements. Sonia Alvarez, Evelina Dagnino, and Arturo Escobar, eds. Pp. 325352. Boulder: Westview Press.

Rodríguez, Clemencia

2001 Fissures in the Mediascape: An International Study of Citizens' Media. Creskill, NJ: Hampton Press.

Rofel, Lisa

2007 Desiring China: Experiments in Neoliberalism, Sexuality and Public Culture. Durham, NC: Duke University Press.

Rubenstein, Anne

1998 Bad Language, Naked Ladies, and Other Threats to the Nation: A Political History of Comic Books in Mexico. Durham, NC: Duke University Press. 
Sang, Tze-Lan Deborah

2003 The Emerging Lesbian: Female Same-Sex Desire in Modern China. Chicago: University of Chicago Press.

Schein, Louisa

2002 Mapping Hmong Media in Diasporic Space. In Media Worlds: Anthropology on New Terrain. Faye D. Ginsburg, Lila Abu-Lughod, and Brian Larkin, eds. Pp. 229-244. Berkeley: University of California Press.

Sedgwick, Eve Kosofsky

1990 Epistemology of the Closet. Berkeley: University of California Press.

Sinclair, John

1999 Latin American Television: A Global View. New York: Oxford University Press.

Sirias, Tania, and Edgar Barbarena

2006 Más voces internacionales en defensa del aborto terapéutico. El Nuevo Diario, November 18. Electronic document, http://www.elnuevodiario.com.ni, accessed December 18, 2006.

Sirias, Tania, and Yaoska Dávila

2006 Médicos consternados. El Nuevo Diario, October 28. Electronic document, http://www.elnuevodiario.com.ni, accessed December 18, 2006.

Skidmore, Thomas E.

1999 Brazil: Five Centuries of Change. Oxford: Oxford University Press.

Smith, James H., and Jeffrey W. Mantz

2006 Do Cellular Phones Dream of Civil War? The Mystification of Production and the Consequences of Technology Fetishism in the Eastern Congo. In Inclusion and Exclusion in the Global Arena. Max Kirsch, ed. Pp. 71-93. New York: Routledge Press.

Thayer, Millie

1997 Identity, Revolution and Democracy: Lesbian Movements in Central America. Social Problems 44(3):386-406.

Turner, Terrence

1992 Defiant Images: The Kayapo Appropriation of Video. Anthropology Today 8(6):516.

2002 Representation, Politics and Cultural Imagination in Indigenous Video: General Points and Kayapo Examples. In Media Worlds: Anthropology on New Terrain. Faye D. Ginsburg, Lila Abu-Lughod, and Brian Larkin, eds. Pp. 75-89. Berkeley: University of California Press.

Vaid, Urvashi

1995 Virtual Equality: The Mainstreaming of Gay and Lesbian Liberation. New York: Anchor.

Van Gisel, Marike

N.d. Mujeres lesbianas en Managua. Unpublished MS, Fundación Xochiquetzal, Managua, Nicaragua.

Velásquez Sevilla, Mirna, and Ary Neil Pantoja

2003 Abortistas excomulgados. La Prensa, February 24. Electronic document, http://www.laprensa.com.ni, accessed December 18, 2006.

Vigíl, María López

2006 Un cambio dramático y una tragedia cultural. Envio Digital, Managua, November. Electronic document, http://www.envio.org.ni, accessed December 3, 2006.

Walker, Thomas W.

1991 Revolution and Counterrevolution in Nicaragua. Boulder: Westview Press.

2003 Nicaragua: The Land of Sandino. 4th ed. Boulder: Westview Press. 
Warner, Michael

1999 The Trouble with Normal: Sex, Politics, and the Ethics of Queer Life. New York: Free Press.

Warren, Kay B.

1998 Indigenous Movements and Their Critics: Pan-Maya Activism in Guatemala. Princeton: Princeton University Press.

Weiner, James F.

1997 Televisualist Anthropology: Representation, Aesthetics, Politics. Current Anthropology 38(2):197-235.

Whisnant, David

1995 Rascally Signs in Sacred Places: The Politics of Culture in Nicaragua. Durham, NC: University of North Carolina Press.

Williams, Raymond

1974 Television: Technology and Cultural Form. Hanover, NH: Wesleyan University Press. 